Publisher's Note: The following information is printed in accordance with U.S. postal regulations: Statement of Ownership, Management and Circulation (required by 39 U.S.C. 3685). 1. Title of Publication: JOURNAL OF INTERAMERICAN STUDIES AND WORLD AFFAIRS. 2. Date of Filing: October 15, 1976. 3. Frequency of Issue: Quarterly. 3A. No. of Issues Published Annually: 4 (four). 3B. Annual Subscription Price: institutions, $\$ 22.50$; individuals, $\$ 13.50$. 4. Location of Known Office of Publication: 275 South Beverly Drive, Beverly Hills (Los Angeles), California 90212.5 . Location of the Headquarters or General Business Offices of the Publishers: 275 South Beverly Drive, Beverly Hills (Los Angeles), California 90212. 6. Names and Complete Addresses of Publisher, Editor, and Managing Editor: Publisher: Sara Miller McCune, 1102 South Oakhurst Street, Los Angeles, California 90035; Editor: John P. Harrison, Box 248134, Univ. of Miami, Coral Gables, FL 33124; Managing Editor: None. 7. Owner (If owned by a corporation, its name and address must be stated and also immediately thereunder the names and addresses of stockholders owning or holding $1 \%$ or more of total amount of stock. If not owned by a corporation, the names and addresses of the individual owners must be given. If owned by a partnership or other unincorporated firm, its name and address, as well as. that of each individual must be given.): Sage Publications, Inc., 275 South Beverly Drive, Beverly Hills, California 90212; Sara Miller McCune, 1102 South Oakhurst Street, Los Angeles, California 90035; Marvin Sirot, Mohawk Lane, Greenwich, Connecticut 06830; Gustave Sirot, Wingate Road, Guilford, Connecticut 06340; John B. Hurford, 220 East 63rd Street, New York, New York 10021; Albert L. Zesiger, 1125 Fifth Avenue, New York, New York 10028; Judith C. Zesiger, 1125 Fifth Avenue, New York, New York 10028. 8. Known Bondholders, Mortgagees, and Other Security Holders Owning or Holding $1 \%$ or More of Total Amount of Bonds, Mortgages or Other Securities: None. 9. For Completion by Nonprofit Organizations Authorized to Mail at Special Rates (Section 132.122, PSM): Not Applicable.

10. Extent and Nature of Circulation

A. Total no. copies printed (net press run) ...

Av. No. Copies
Each Issue
During
Preceding
12 Months

B. Paid circulation:

1. Sales through dealers and carriers, street

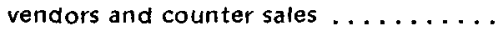

2. Mail subscriptions ..............

C. Total paid circulation

(sum of $10 \mathrm{B1}$ and 10B2) ...........

D. Free distribution by mail, carrier or other means: samples, complimentary, and other free copies .................

E. Total distribution (sum of $\mathrm{C} \& \mathrm{D}$ ) $\ldots \ldots$.

F. Copies not distributed:

1. Office use, left-over, unaccounted, spoiled after printing ........... 2. Returns from news agents ..........

G. Total (sum of $E, F 1$ and 2-should equal net press run shown in $A) \ldots \ldots \ldots$

$$
1638
$$

Actual No. of Copies of Single Issue Published Nearest to Filing Date

1600

11. I certify that the statements made by me above are correct and complete. (Signed) Sara Miller McCune, Publisher and President. 12. 39 U.S.C. 3626 provides in pertinent part: "No person who would have been entitled to mail matter under former section $\mathbf{4 3 5 9}$ of this title shall mail such matter at the rates provided under this subsection unless he files annually with the Postal Service a written request for permission to mail matter at such rates." In accordance with the provisions of this statute, I hereby request permission to mail the publication named in Item 1 at the reduced postage rates presently authorized by 39 U.S.C. 3626. (Signed) Sara Miller McCune, Publisher and President. 


\section{Advertising Supplement: \\ Journal of Interamerican Studies and World Affairs}

This supplement has been prepared especially for our readers to bring them information and announcements of professional interest. By placing advertisements in the pages of this journal. our advertisers have indicated a desire to communicate with our readers. We hope our readers will acknowledge their indirect support of the journal and its purposes by mentioning the journal in correspondence with advertisers.

NEW!
edited by Everett M. Rogers
The disappointing performance of mass communications in fostering development in
Latin America has led to alternative conceptions of how to use communication in de-
veloping societies, as well as a redefinition of what development really is. This issue
explores these alternatives and examines the implications that new paradigms will have
for communication research and training, and for national governments and technical
assistance agencies trying to promote development.
CONTENTS: New Perspectives on Communication and Development: Overview (E. M. Rogers)
Alien Premises, Objectives, and Methods in Latin American Communication Research (L. R.
Beltran S.) Communication of Agricultural Innovations in Latin America: The Need for New
Models (J. D. Bordenave) The Diffusion on Innovations and the Issue of Equity in Rural De.
velopment (N.G. Roling. J. Ascroft and F. Wa Chege) The Communication Effects Gap: A Field
Experiment on Television and Agricultural Ignorance in India (P. M. Shingi and B. Mody) How
Does Communication Interface with Change? (G. C. Whiting) Communication and Development:
The Passing of the Dominant Paradigm (E. M. Rogers)
Originally published in Communication Research, April 1976
148 pages / ISBN 0-8039-0733-8 / \$3.95

SAGE PUBLICATIONS LTD St George's House / 44 Hatton Garden London EC1N 8ER
SAGE PUBLICATIONS, INC.

275 South Beverly Drive

Beverly Hills, California 90212

Please mention Journal of Interamerican Studies and World Affairs when writing advertisers. 


\title{
URBANIZATION AND INEQUALITY \\ The Political Economy of Urban and Rural Development in Latin America
}

\author{
(Latin American Urban Research, Volume 5) \\ edited by WAYNE A. CORNELIUS and FELICITY M. TRUEBLOOD
}

Distinguished contributors from six disciplines illustrate how government decisions have influenced the distribution of wealth and population, identify the frequent contradictions in such government programs, and assess the experience of several Latin American countries in using a variety of policy instruments to ameliorate the inequities accompanying urban-industrial development.

Introduction

\section{CONTENTS}

Part I. Urbanization and Uneven Development

Chapter 1. Internal Colonialism: Problems of Definition and Measurement

Part II. The Rural-Urban Interface

Chapter 2. Urbanization in Mexico: The View from Tzintzuntzan

Chapter 3. Center and Periphery in the Development Process:

The Case of Peru

Part III. The Political Economy of Urban Poverty

Chapter 4. "Tertiarization" and Urban Poverty in Latin America

Chapter 5. The Political Economy of Lower Class Areas in Mexico City: Societal Constraints on Local Business Prospects

Chapter 6. Housing Finance in Brazil: Towards a New Distribution of Wealth

Chapter 7. Housing the Urban Poor in Chile: Contrasting Experiences Under "Christian Democracy" and "Unidad Popular"

Part IV. Public Policies as Determinants of Urban Growth and Rural-Urban Inequalities

Chapter 8. Urban Growth Policy in Brazil: Intended and Accidental

Chapter 9. Political Economy and the Management of Urban Development in Brazit

Chapter 10. Public Policy and Regional Incomes in Peru

Part V. Regional Development Programs and Rural.Urban Inequalities

Chapter 11. Urban and Regional Development Programs in Colombia Since 1951

Chapter 12. Regional Development and Interregional Equity: A Mexican Case Study

Chapter 13. The Regional Strategy of "Unidad Popular" in Chile

1975

ISBN 0.8039-0437.1/320 pages/(cloth)

ISBN 0.8039-0602-1/320 pages/(paper)

SAGE PUBLICATIONS LTD 


\section{MIGRATION AND ADAPTATION Tzintzuntzan Peasants in Mexico City}

\section{by ROBERT V. KEMPER, Southern Methodist University}

A new study presenting a description and analysis of rural migrants and their adaptation to life in a rapidly growing metropolitan setting, this volume deals with a microcosm of Mexican urbanization: emigration from the traditional peasant village of Tzintzuntzan, Michocan to Mexico City. Professor Kemper reports on the background of the migrants as well as on their cultural and social adjustments to an urban environment. A model of rural-urban migrattion applicable to similar populations in other developing nations is also presented and will be of interest to anthropologists and urban specialists involved in a variety of disciplines.

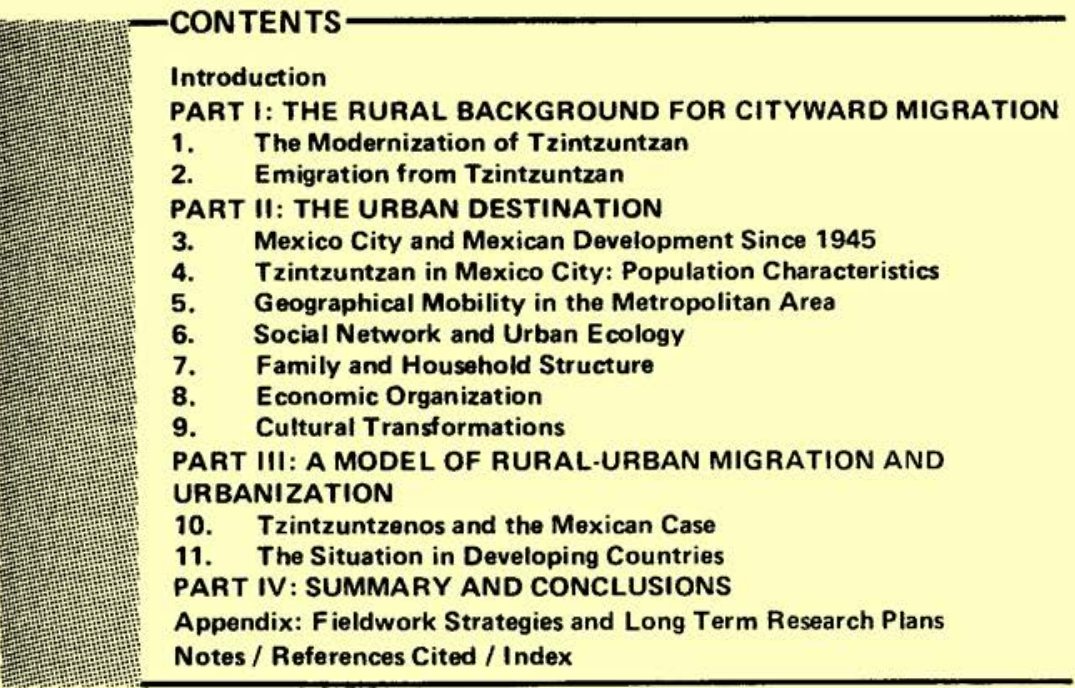

"Tzintzuntzan is especially well suited for a microcosmic study of the emigration process. On the one hand, since the bulk of the emigration is recent, we can deal with real people, and not simply with statistics. And these people are known, as are their families, their socioeconomic status, and their histories, to an extent not normally the case." - from Chapter 1

Volume 43 Sage Library of Social Research ISBN 0-8039-0687-0 cloth $\$ 11.00^{*}$ April 1977 (tent.) 224 pages (tent.) ISBN 0-8039-0688-9 paper \$ 6.00*

SAGE PUBLICATIONS LTD St George's House / 44 Hatton Garden London ECIN 8ER
SAGE PUBLICATIONS, INC

275 South Beverly Drive

Beverly Hills, California 90212 


\title{
LATIN AMERICA, THE COLD WAR, AND THE WORLD POWERS, 1945- 1973: A Study in Diplomatic History
}

\author{
by F. PARKINSON, Law, University College (London)
}

An analysis-placed in careful historical perspective-of the background and development of the new diplomatic climate pervading Latin America. Underscores the re-emerging importance of intra-Latin American issues and the notion of balance of power.

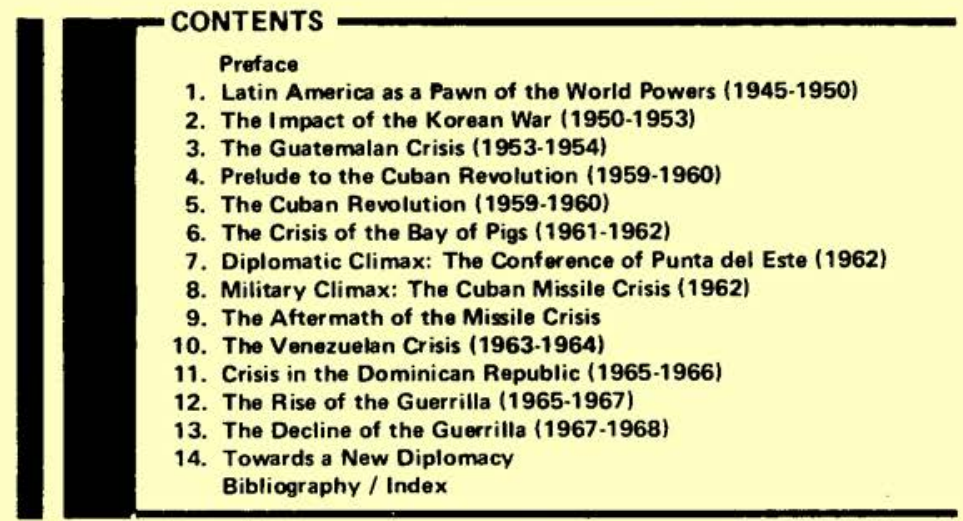

"After so many U.S. monographs in which facts are sloppily presented and professional jargon replaces scholarly craftsmanship, it is a pleasure to read a text which is coldly lucid, with each statement carefully documented and with an ample bibliography. In preparing his monograph, Parkinson not only scoured the literature, he toured Latin America in search of new insights and information. The result is a work which opens up the whole field of what might be called Latin American diplomacy."

\section{- California Institute of International Studies, September 1975}

"This comprehensive and well-documented textbook on the foreign policies of the Latin American countries during the postwar period provides a necessary addition to any Latin American history.... This book is to be warmly recommended to all concerned with Latin American affairs; it provides an analytical background to, rather than a synthetic appraisal of, the problems facing the region today."

-BOLSA Review,

Lloyds Bank International

Volume 9 Sage Library of Social Research 1974 288 pages
ISBN 0-8039-0413-4 cloth $\$ 12.00$ ISBN 0-8039-0412-6 paper $\$ 7.00$

\section{SAGE PUBLICATIONS LTD 44 Hatton Garden, London EC1N 8ER SAGE PUBLICATIONS, INC 275 S. Beverly Dr. / Beverly Hills, CA. 90212}




\title{
MILITARY RULE \\ IN LATIN AMERICA \\ Functions, Consequences and Perspectives
}

\author{
edited by PHILIPPE C. SCHMITTER, University of Chicago
}

The papers collected here were selected to represent three broad areas of inquiry: the political function of direct military rule, the policy consequences of military intervention and external aid, and the prospective impact of both on regional and global political systems. This volume suggests "there is growing evidence that the recipient military establishments have become increasingly less willing to accept the subordinate and limited strategic posture which has accompanied external support."

\section{CONTENTS}

Introduction Philippe C. Schmitter

I. CHANGING FUNCTIONS OF MILITARY RULE

Military Revolutions and National Independence in Latin America: 1968-1971 Alain Rouquie

II. CONSEQUENCES OF MILITARY RULE AND MILITARY AID

Assessing the Impact of Military Rule: Alternative Approaches Jerry L. Weaver

Foreign Military Assistance, National Military Spending and Military Rule in Latin America Philippe C. Schmitter

III. FUTURE PERSPECTIVES FOR ARMS CONTROL AND MILITARY RULE

The Prospects for Arms Control in Latin America: The Strategic Dimensions Geoffrey Kemp

United States Foreign Policy and Latin American Military Rule James $R$. Kurth

" fresh original, first-rate pieces of scholarship which explore some previously unexplored areas and subject to empirical testing and analysis some untested, unanalyzed-but fairly commonly-held-propositions, explanations, and assumptions having to do with the armed forces."

$$
\text { - JOURNAL OF LATIN AMERICAN STUDIES }
$$

"This valuable collection is for the specialist . . Each author presents a useful summary of the relevant literature, and a number of previous propositions are challenged or modified." - PERSPECTIVE

"The volume's innovative features relate to its strong emphasis on theoretical considerations and scientific method. It should find its greatest appeal at the graduate level, given its rather technical and sophisticated approaches."

$$
\text { - CHOICE }
$$

Volume 3 Sage Research Progress Series on War, Revolution, and Peacekeeping
1973
ISBN 0-8039-0242-5
cloth
$\$ 17.50$
334 pages
ISBN $0-8039 \cdot 0249-2$
paper
$\$ 7.50$

SAGE PUBLICATIONS - The Publishers of Professional Social Science 275 South Beverly Drive / Beverly Hills, California 90212

St George's House / 44 Hatton Garden / London EC1N 8 ER

Please mention Journal of Interamerican Studies and World Affairs when writing advertisers. 


\section{Books for Specialists in LATIN AMERICAN STUDIES}

\section{PEASANTS, POWER AND APPLIED SOCIAL CHANGE}

Edited bY HENRY F. DOBYNS, PAUL L. DOUGHTY and HAROLD

D. LASSWELL

Analyzes one of the most exciting instances of planned social intervention in the history of modern social science-the Cornell Peru Project, which assisted in the self-transformation of peasants in the hacienda of Vicos from what was essentially a condition of serfdom to one of community involvement in economic, political and social development. The relevance of this study to contemporary trends in anthropology is also developed.

224pp / $1971 / \$ 12.50$

\section{THE MAJORITY OF ONE}

\section{by MINERVA ETZIONI with a Preface by RICHARD A. FALK}

Studies the relationships established over the last 20 years in the handling of political and security matters between the UN and the OAS (a relationship which is skewed by the strength of US influence).

"This is an intellectually stimulating book. Its systematic treatment of problems in international organization politics is refreshing. It is well written and clearly argued." - The Annals

238pp / $1969 / \$ 7.50$

\section{LATIN AMERICAN URBAN POLICIES AND THE SOCIAL SCIENCES}

\section{Edited by JOHN MILLER and RALPH A. GAKENHEIMER}

Addresses various policy issues related to urban development in Latin America at international, national and local levels-from the points of view of different social sciences. The problems and potentials generated by rapid urbanization and the use of the social sciences for understanding and guiding urbanization and the process of national growth are treated extensively.

384pp / $1971 / \$ 15.00$

SAGE PUBLICATIONS - The Publishers of Professional Social Science 275 South Beverly Drive / Beverly Hills, California 90212

St George's House / 44 Hatton Garden / London EC1N 8ER 


\section{LATIN AMERICAN INTERNATIONAL AFFAIRS}

\section{Sponsored by the Center for Inter-American Relations}

Editors: Ronald G. Hellman, Director of Public Affairs, Center for Inter-American Relations H. Jon Rosenbaum, Department of Political Science,
City University of New York

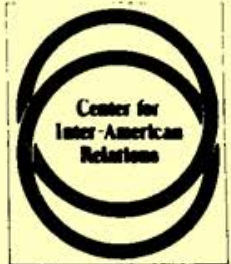

The first volume .........

\section{LATIN AMERICA: The Search for a New International Role}

What is Latin Ameria's role in international relations today? What will it be in ten years?

Drawing from Latin American scholarship and commentary of a type heretofore only infrequently published, the editors present essays dealing with problems facing Latin American nations as they develop their own spheres of influence in the Western hemisphere, and in the total picture of world affairs.

As a whole, this biennial series will be exclusively devoted to Latin American international relations. Each volume will contain outstanding, commissioned articles by leading authorities in this field.

Introduction

RONALO G. HELLMAN \& H. JON ROSENBAuM

Tronds in Inter.American Rolations

PAAT I DOMESTIC FACTOAS ON INTER. AMERICAN FOREIGN POLICY MAKING

The Kitzch in Hemispheric Realpolitik KALMAN H. SILVERT

United States Policies and Latin American Realities IRVING LOUIS HOROWITZ

The Allience for Progen ARTHUA SCHLESINGER, JR.

PART II INTAA-LATIN AMERICAN RELATIONS

Problems, Perapectives, and Modes of Analyes EOWARDS MILENKY

Rru's Diplometic OHtenvive ROBEAT H. SWANSBROUGH YALE H. FERGUSON

\section{CONTENTS}

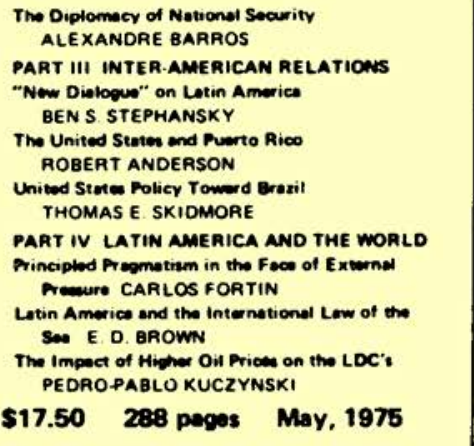

$A(0)$ SAGE Publication-distributed exclusively by:

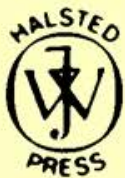

\section{HALSTED PRESS}

A Division of JOHN WILEY \& SONS. Inc 605 Third Avenue. New York. N.Y. 10016 
- LEgISLATIVE INSTITUTION BUILDING IN BRAZIL, COSTA RICA AND LEBANON by Abdo I. Baaklini and James J. Heaphey (03-027)

Arguing against the doctrine of political neutrality for legislative staffs, this paper studies the empirical situations in three developing countries as juxtaposed to the historical parliament in England and the contemporary U.S. Congress. The authors contend that the values of a legislature would be lost if dominated by a bureaucracy of staff experts who could stifle the political function of the legislature.

- THE IMPACT OF REVOLUTION: A Cumparative Analysis of Mexico and Bolivia by Susan Eckstein (06-016)

An analysis of economic and political developments in two Latin American countries which have undergone "capitalist revolutions," where outcomes are shown to be shaped more by international economic and political forces and by the use of state power than by the conditions inducing "popular" forces to rebel.

\section{- TERRORISM IN LATIN AMERICA by Ernst Halperin (480033)}

Analyzing the strategy, tactics, social origins, and ideology of terrorism. this paper declares that it is "a vigorous reaction against economic stagnation and social putrefaction "by the most energetic members of the young, educated class - a bid for power and simultaneousily a bid for employment.

- A COMPARISON OF U.S. AND MULTILATERAL AID RECIPIENTS IN LATIN AMERICA, 1957.1971 by Witliam Loehr. David Price, and Satish Raichur (02.040) Contrasting the two types of aid-bilateral and multilateral-and considering the characteristics of the recipients of each, this paper isolates those political and economic factors that characterize the donor-recipient relationship in Latin America.

- REgIONAL INTEgRATION: A Comparison of European and Central American Dynamics by Louis A. McCall (02-041)

Are the dynamics of integration the same from region to region? This paper applies multivariate techniques to the study of regional integration-addressing the problem within the context of a causally determined axiomatic theory-derived from an empirical assessment of the European and Central American experiences.

- CUBAN ECONOMIC POLICY AND IDEOLOGY: The Ten Million Ton Sugar Harvest by Sergio Roca (02-044)

A detailed examination of the failure of the ten million ton harvest and the various factors which caused and defined that failure-particularly the concurrent output losses in non-sugar sectors of the economy-this paper speculates on the extent to which the ideological tenets of the Moral Economy contributed to the final outcome.

SAGE PUBLICATIONS, INC 275 South Beverty Drive

Beverly Hills, Calıfornı 90212
SAGE PUBLICATIONS LTO

St George's House / 44 Hatton Garden London ECIN $8 E R$ 


\section{DEVELOPMENT \\ AND \\ CFIANGE}

An interdisciplinary journal devoted to critical analysis and dialogue concerning current issues of Third World development. Recurring subject areas include problems of rural development, education and manpower planning, the impact of multinational corporations, the transfer of technology, the role of the bureaucracy, spatial dimensions of development, workers' participation, and industrialization. The journal occasionally devotes an entire issue to a particular theme.

Editorial Board at the Institute of Social Studies, The Hague: Martin Doornbos, Kurt Martin, Brian Van Arkadie, Frits Wils, with an international Advisory Board.

Contents

Volume 8 Number 1

January 1977

State Capitalism and the Third World

JAMES PETRAS

Organization is Not Equity: Theories of Political Integration BERNARD SCHAFFER

The Neocolonial Integration of Kenyan Peasants

GEOFF LAMB

Multinational Corporations and Basic Needs Development

KEITH GRIFFEN

The Economics of 'Gobar-Gas' Versus Fertilizer: A Critique of Intermediate

Technology

RICHARD DISNEY

Economic Irrationality Among Pastoral Peoples: Myth or Reality

IAN LIVINGSTONE

Export Trends in East Africa

LESLIE STEIN

Frequency: Quarterly in January. April, July, October

Subscription rates for U.S. Add $\$ 1.00$ for subscriptions elsewhere.

Institutional Individual

$\begin{array}{lll}\text { One-year } & \$ 22.00 & \$ 14.00 \\ \text { Two-year } & \$ 43.00 & \$ 27.00 \\ \text { Three-year } & \$ 63.00 & \$ 39.00\end{array}$

For further details contact the Publisher

SAGE Publications Ltd

44 Hatton Garden

london EC.1N 8ER

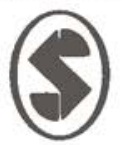

SAGE Publications Inc

275 South Beverly Drive

Beverly Ilills, California 90212 


\title{
LATIN AMERICAN URBAN RESEARCH
}

ANNUAL SERIES

\author{
Volume 5 - URBANIZATION AND INEQUALITY: The Political \\ Economy of Urban and Rural Development in Latin Ameriça \\ Edited by Wayne A. Cornelius and Felicity M. Trueblood
}

Distinguished contributors from six disciplines illustrate how government decisions have influenced the distribution of wealth and population, idemify the frequent contradictions in such government programs, and assese the experience of severat Latiri American countries in using a variety of polidy instruments to ameliorate the inequities accompanying urban-industrial development.

$1975 / 320$ pages $/ \$ 17.50$ (c) $\$ 7.50(p)$

\section{Volume 4 - ANTHROPOLOGI- CAL PERSPECTIVES ON LATIN AMERICAN URBANIZATION}

Edited by Wayne A. Cornelius and Felicity M. Trueblood

The major problems explored in this volume relate to the process of rural. urban migration, the urban assimilation of migrants, patterns of urban community development and organization, and the interrelationships of city and country. side in Latin American countries.

$1974 / 320$ pages $/ \$ 17.50$

\section{Volume 3 - NATIONAL-LOCAL} LINKAGES: The Interrelationships of Urban and National Politics in Latin America

Edited by Francine F. Rabinovitz and Felicity M. Trueblood

Describes and analyzes the interrelationships between national politics, policy, urban politics and development. This volume also includes an extensive bibliography, and an appendix, surveying urban research and teaching facilities in the Caribbean.

$1973 / 320$ pages/\$17.50

\section{Volume 2 - REGIONAL AND URBAN DEVELOPMENT POLICIES: A Latin American Perspective}

Edited by Guillermo Geisse and Jorge $E$. Hardoy

Provides an introductory overview of theoretical bases for, and operating ex. periences with, regional and urban development efforts to date in Latin America. Extensive bibliography. $1972 / 304$ pages/\$17.50

\section{Volume 1 - LATIN AMERICAN URBAN RESEARCH}

Edited by Francine $F$. Rabinovitz and
Felicity $M$. Trueblood

Concentrates on four major themes: urban migration and marginality; urban cultures; government institutions and decision-making; policy problems in Latin American urban areas. Includes exten. sive bibliography and list of research centers.

$1971 / 320$ pages $/ \$ 17.50$ (c) $\$ 7.50(p)$

*Standing orders may be entered for forthcoming volumes in this series at $\$ 15.00$ per volume.

\author{
SAGE PUBLICATIONS, INC \\ 275 South Beverly Drive \\ Beverly Hills, California 90212
}

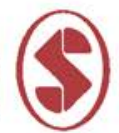

SAGE PUBLICATIONS LTD

St Georqe's House / 44 Hatton Garden London EC1N 8ER 